\title{
Wyzwania rozwojowe na obszarach wiejskich w województwie mazowieckim
}

\section{Jerzy Bański}

\section{STRESZCZENIE}

W strukturze przestrzennej województwa mazowieckiego można, w sposób bardzo ogólny, wyróżnić dwa podstawowe elementy - Warszawę i obszary wiejskie w jej sąsiedztwie oraz pozostałe tereny, z ośrodkami subregionalnymi, mniejszymi miastami i terenami wiejskimi. Nowoczesne struktury gospodarki z innowacyjnymi branżami produkcji i usług koncentrują się w Warszawie oraz w mniejszym stopniu w Radomiu i Płocku. Na pozostałym obszarze województwa pierwszoplanową rolę odgrywa sektor rolnictwa charakteryzujący się dużym zróżnicowaniem przestrzennym.

Celem opracowania jest zdiagnozowanie współczesnych zmian w strukturze przestrzennej obszarów wiejskich woj. mazowieckiego i związanych z nimi wyzwań rozwojowych. Podstawowy materiał statystyczny, stwarzający możliwość szczegółowej analizy, pochodzi z Powszechnego Spisu Rolnego 2010 oraz banku danych lokalnych GUS. Opracowanie składa się z trzech części. Pierwsza z nich przedstawia ocenę Strategii rozwoju województwa mazowieckiego, która kształtowała m.in. rozwój obszarów wiejskich na przełomie pierwszej i drugiej dekady tego wieku oraz omawia stan zaawansowania prac planistycznych na terenach wiejskich. Druga część charakteryzuje strukturę funkcjonalną obszarów wiejskich Mazowsza i jej zmiany oraz diagnozuje stan rozwoju społeczno-ekonomicznego wsi. W trzeciej części, mającej charakter dyskusyjny, omówiono współczesne trendy rozwojowe obszarów wiejskich i związane z nimi wyzwania.

Współczesne zmiany na obszarach wiejskich woj. mazowieckiego zwiększają jego polaryzację przestrzenną. Przeważają zjawiska korzystne dla rozwoju społeczno-ekonomicznego regionu, ale ich natężenie jest wyraźnie zróżnicowane, co powoduje wzrost różnic przestrzennych w regionie. Najbardziej dynamiczne zmiany występują w warszawskim obszarze metropolitalnym i w sąsiedztwie ośrodków subregionalnych. Dynamika zmian na obszarach wiejskich, położonych w większej odległości od ośrodków centralnych, jest mniejsza i wiąże się głównie z rozwojem sektora żywnościowego a rzadziej pojawianiem się nowych funkcji gospodarczych. Podstawowe wyzwania wynikają z kształtowania racjonalnej struktury gospodarstw rolnych i odpowiednich kierunków ich produkcji.

Słowa kluczowe: obszary wiejskie, Mazowsze, struktura przestrzenna, rozwój przestrzenny, rolnictwo

\section{Wstęp}

W strukturze przestrzennej województwa mazowieckiego można, w sposób bardzo ogólny, wyróżnić dwa podstawowe elementy - Warszawę i obszary w jej sąsiedztwie oraz pozostałe tereny, z ośrodkami subregionalnymi, mniejszymi miastami i terenami wiejskimi. Dzięki dynamicznie rozwijającej się stolicy, region mazowiecki ma nowoczesną strukturę gospodarki z innowacyjnymi branżami produkcji i usług, ale koncentrują się one w Warszawie [Mazowsze 2020 2013]. Na pozostałym obszarze, z wyjątkiem Radomia i Płocka, struktura gospodarki nie odbiega od „standardów krajowych”. W przypadku obszarów wiejskich można nawet mówić, że jest ona bardzo tradycyjna, bo ściśle związana z sektorem rolnictwa. 
Jednakże w zakresie samego rolnictwa, na obszarze Mazowsza, traktowanego jako jednostkę terytorialna, występuje bardzo duże zróżnicowanie przestrzenne - $\mathrm{z}$ jednej strony działają bardzo nowoczesne i towarowe gospodarstwa (np. grójecki region sadowniczy, radomski region warzywniczy, ostrołęcki region mleczarski), z drugiej zaś strony, we wschodniej części regionu jest duża grupa gospodarstw niskotowarowych.

Na znacznej powierzchni obszarów wiejskich trudno jest wskazać alternatywne dla rolnictwa kierunki rozwoju. Biorąc pod uwagę turystykę, Mazowsze nie ma szczególnych walorów przyrodniczych i krajobrazowych [Strategia rozwoju turystyki...2015], dlatego turystyka wiejska nie jest wiodącym kierunkiem rozwoju i może być raczej funkcją uzupełniającą w kilku bardziej atrakcyjnych obszarach. Większe znaczenie od turystyki ma rekreacja związana z wypoczynkiem sobotnio-niedzielnym na obszarach letniskowych. Również leśnictwo ze średnią powierzchnią lasów w regionie na poziomie 22,5\% (czyli około 7\% mniej niż przeciętnie w kraju) nie może stanowić perspektywicznego kierunku rozwoju. Należy oczekiwać, że sektor rolnictwa utrzyma swoją wiodącą rolę na tradycyjnych obszarach wiejskich, natomiast w strefie oddziaływania Warszawy i dwóch dużych ośrodków subregionalnych wyzwania rozwojowe będą związane z mieszkalnictwem, usługami i drobną produkcją oraz codziennymi migracjami wahadłowymi.

\section{Cel opracowania i uwagi metodyczne}

Celem opracowania jest zdiagnozowanie współczesnych zmian w strukturze przestrzennej obszarów wiejskich woj. mazowieckiego i związanych z nimi wyzwań rozwojowych. Wykorzystano rezultaty wcześniejszych badań i ekspertyz autora, które były wykonane na początku tej dekady. Podstawowy materiał statystyczny, stwarzający możliwość szczegółowej analizy, pochodzi z Powszechnego Spisu Rolnego 2010 oraz banku danych lokalnych GUS. Opracowanie składa się z kilku komplementarnych części. Pierwsza z nich przedstawia ocenę Strategii rozwoju województwa mazowieckiego do 2020 roku [2006], w której wskazano m.in. rozwój obszarów wiejskich na przełomie pierwszej i drugiej dekady tego wieku oraz omówiono stan zaawansowania prac planistycznych na terenach wiejskich. Druga część charakteryzuje strukturę funkcjonalną obszarów wiejskich Mazowsza i jej zmiany oraz diagnozuje stan rozwoju społeczno-ekonomicznego wsi. W trzeciej części omówiono współczesne trendy rozwojowe obszarów wiejskich i związane z nimi wyzwania.

W pracy wykorzystano rezultaty badań, które opierają się na różnorodnych rozwiązaniach metodycznych. Ocena tematyki wiejskiej, podejmowanej w strategiach wojewódzkich, została wykonana na podstawie 17 wskaźników (np. rola, jaką odgrywa tematyka wiejska w części diagnostycznej strategii, jakość danych statystycznych, identyfikacja procesów społeczno-gospodarczych na wsi, różnorodność i szczegółowość ustaleń strategicznych, oryginalność rozwiązań strategicznych itp.), którym przypisano określony zakres punktów (szczegóły metody - Bański i in. 2009). Struktura funkcjonalna obszarów wiejskich została zidentyfikowana na podstawie kilkunastu statycznych i dynamicznych cech diagnostycz- 
nych. Po przeprowadzeniu normalizacji wskaźników posłużyły one do kwalifikowania gmin wiejskich do określonych typów funkcjonalnych [Bański 2014]. Metoda wskaźnikowa została też wykorzystana do oceny stanu rozwoju społeczno-ekonomicznego obszarów wiejskich.

\section{Obszary wiejskie Mazowsza w planowaniu przestrzennym}

Dokumenty planistyczne, w tym strategie rozwoju i plany zagospodarowania przestrzennego, są dokumentami kształtującymi procesy rozwojowe regionu, stanowią też punkt odniesienia dla powstających na poziomie regionu innych dokumentów programowych i planistycznych. W 2010 r. powstało opracowanie podejmujące próbę szczegółowej i krytycznej analizy strategii wojewódzkich w zakresie problematyki dotyczącej obszarów wiejskich [Bański i in. 2009]. Głównym celem badania było zdiagnozowanie i ocena aktualnych wojewódzkich strategii rozwoju pod kątem celów i kierunków rozwoju wyznaczanych przez nie dla obszarów wiejskich. W przypadku woj. mazowieckiego ocenie poddano Strategię rozwoju województwa mazowieckiego do roku 2020 (aktualizacja), która kształtowała rozwój regionu w latach 2006-2013. Aktualnie obowiązuje Strategia rozwoju województwa mazowieckiego do 2030 roku [2013].

W części diagnostycznej ocenianej Strategii poświęca się wiele uwagi najważniejszym problemom rozwojowym obszarów wiejskich. Podkreślane jest zróżnicowanie przestrzenne każdego z analizowanych uwarunkowań gospodarczych, społecznych i infrastrukturalnośrodowiskowych. Trafnie opisano też tendencje obserwowane na obszarach wiejskich i ich cechy. Dokument wskazuje na polaryzację gospodarstw rolnych, zróżnicowanie przestrzenne struktury produkcji rolnej, niski poziom wykształcenia właścicieli gospodarstw rolnych, przeludnienie agrarne i starzenie się społeczeństwa, na problemy wydajności systemu energetycznego itp. W części koncepcyjnej Strategii zamieszczono scenariusz wspomagania rozwoju obszarów pozametropolitalnych poprzez, m.in.: tworzenie instytucji i urządzeń wspomagających oddziaływanie Warszawy na otoczenie, budowę sieci połączeń drogowych zapewniających spójność terytorialną oraz budowę powiązań teleinformatycznych zmniejszających dystans cywilizacyjny pomiędzy miastami i obszarami wiejskimi. Stwierdzono, że postępująca degradacja społeczno-gospodarcza obszarów pozametropolitalnych wskazuje na konieczność intensyfikowania działań aktywizujących te obszary. Przede wszystkim zwrócono uwagę na znaczne luki w rozwoju infrastruktury komunikacyjnej, w tym na małą dostępność przestrzenną Warszawy i ośrodków subregionalnych z peryferyjnie zlokalizowanych obszarów wiejskich. Podkreślono też potrzebę wielofunkcyjnego rozwoju obszarów wiejskich. Ocena tematyki wiejskiej podejmowanej w Strategii wykazała, że dokument należy, obok strategii woj. lubelskiego, do najlepiej opracowanych spośród wszystkich regionów (ryc. 1). 


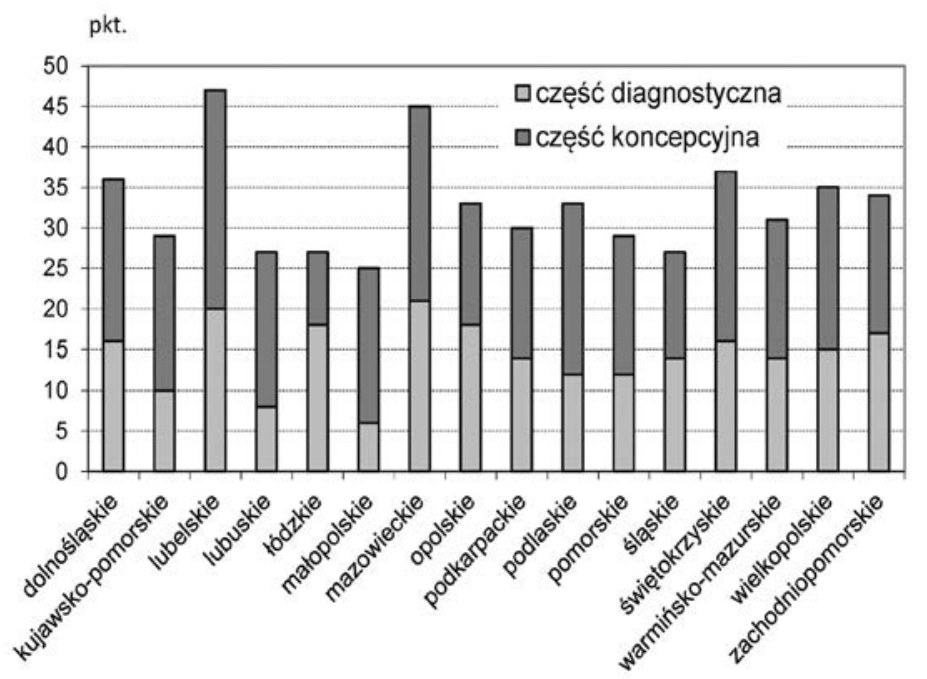

Ryc. 1. Ocena punktowa części diagnostycznej i koncepcyjnej strategii wojewódzkich pod względem ujmowania problematyki obszarów wiejskich

Źródło: J. Bański i in. 2009

Niżej należy ocenić stan zaawansowania planistycznego w mazowieckich gminach, regulowanego przez dwa podstawowe dokumenty: studium uwarunkowań i kierunków zagospodarowania przestrzennego oraz miejscowy plan zagospodarowania przestrzennego. W $2014 \mathrm{r}$. w gminach wiejskich $\mathrm{w}$ kraju udział powierzchni objętej planem miejscowym wynosił przeciętnie 37,7\%, zaś w gminach miejsko-wiejskich - 29,9\% [Bański 2016]. Różnica na korzyść gmin wiejskich wynika z faktu, że ich plany odnoszą się często do całej powierzchni, natomiast $\mathrm{w}$ gminach miejsko-wiejskich przywiązuje się większą wagę do planów obejmujących powierzchnie przewidziane pod konkretne inwestycje, na ogół w mieście lub jego bezpośrednim sąsiedztwie. Potwierdzeniem tego jest przeciętna liczba planów przypadająca na jednostkę terytorialna, w gminach wiejskich - 15, a w miejsko-wiejskich - ponad 23. Gminy wiejskie w woj. mazowieckim, na tle innych regionów, mają dobre pokrycie miejscowymi planami. Jednakże szczegółowe analizy liczebności miejscowych planów w przeliczeniu na 100 km² wykazały pod tym względem bardzo duże zróżnicowanie przestrzenne (ryc. 2).

Natężenie prac planistycznych i poziom pokrycia miejscowymi planami zagospodarowania przestrzennego ma wyraźny związek ze strukturą funkcjonalną obszarów wiejskich. Najmniejsze natężenie prac planistycznych mają gminy typowo rolnicze, w których opracowywane są plany o charakterze ogólnym (obejmujące często całą jednostkę), co jest świadectwem mniejszej presji inwestycyjnej na tych obszarach. Najmniejsza liczebność miejscowych planów występuje wzdłuż granic administracyjnych woj. mazowieckiego. Z kolei największe natężenie prac planistycznych ma miejsce $w$ wielofunkcyjnych gminach wiejskich położonych w sąsiedztwie Warszawy, czyli na terenach atrakcyjnych inwestycyjnie. 


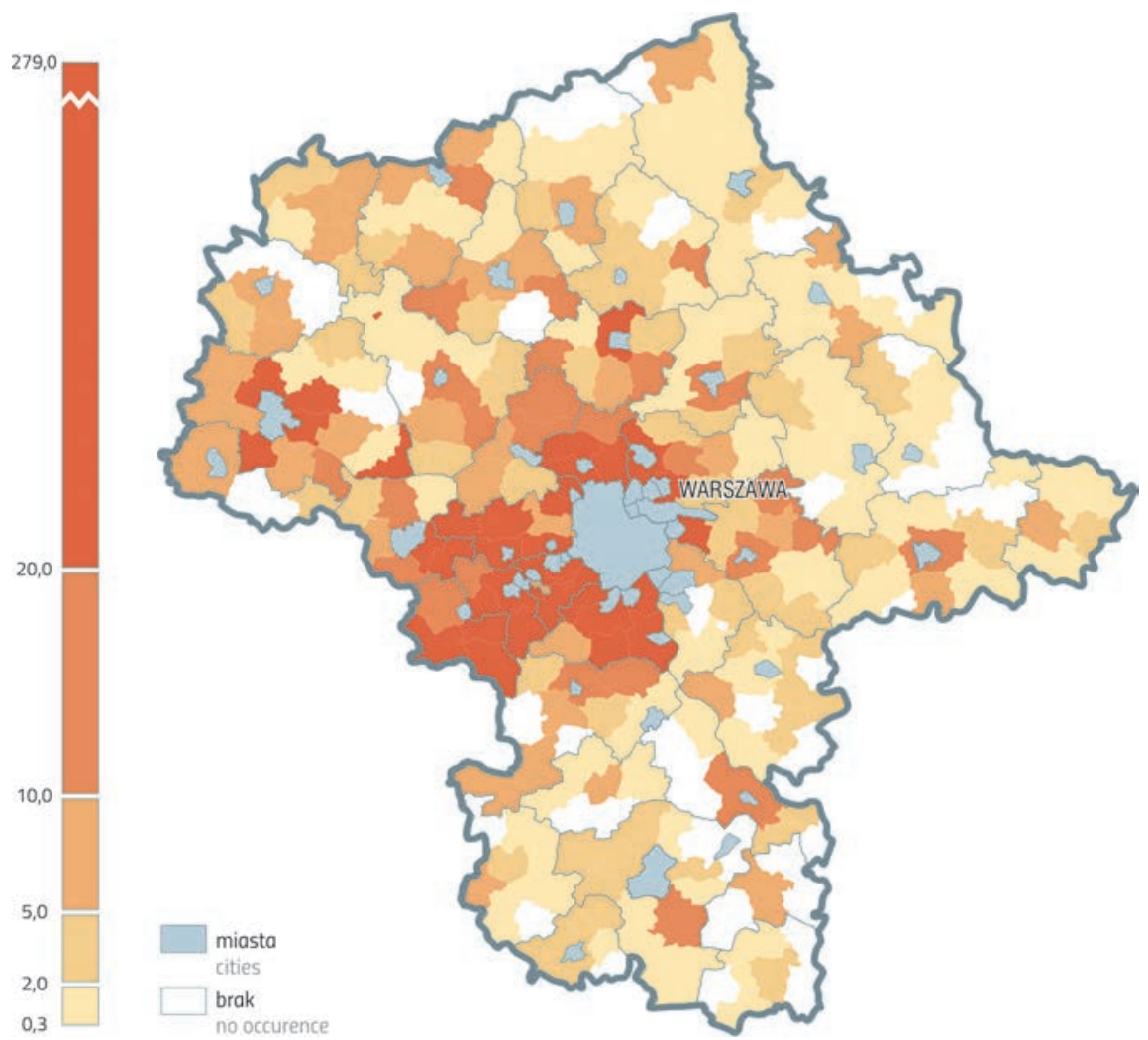

Ryc. 2. Liczba planów zagospodarowania przestrzennego na 100 km² wg gmin, 2013 Źródło: Atlas obszarów wiejskich w Polsce 2016

\section{Struktura funkcjonalna i stan rozwoju społeczno-gospodarczego obszarów wiejskich Mazowsza w zarysie}

Struktura funkcjonalna woj. mazowieckiego ma charakter strefowy i wyraźnie nawiązuje do idei kontinuum miasto-wieś, która zakłada stopniową zmienność zjawisk i procesów społeczno-ekonomicznych w miarę oddalania się od centrum w kierunku peryferii [Bański 2008]. Centrum reprezentuje Warszawa, którą otaczają zurbanizowane gminy wiejskie i miejsko-wiejskie. Te z kolei otoczone są obszarami o funkcjach mieszanych, a dalej w kierunku granic regionu przeważają gminy o funkcjach rolniczych (ryc. 3). Jednakże obraz struktury funkcjonalnej nie jest tak regularny, bo zniekształcają go różne czynniki związane z dostępnością komunikacyjną, lokalizacją ośrodków subregionalnych i innych miast powiatowych oraz z warunkami naturalnymi. 
Warszawa i jej bezpośrednie sąsiedztwo tworzą zwarty obszar zurbanizowany o intensywnych strukturach punktowych i liniowych (produkcja, usługi, komunikacja, mieszkalnictwo, handel) i małym znaczeniu struktur powierzchniowych (rolnictwo, leśnictwo). Wokół stolicy koncentrują się obszary wiejskie charakteryzujące się silną urbanizacją wynikającą z napływu ludności miejskiej i z powstawania nowych osiedli mieszkaniowych. Obszary urbanizujące się o znacznej koncentracji struktur intensywnych (w tym głównie: mieszkalnictwa, usług i produkcji) występują wokół Warszawy, z wyjątkiem wschodniej części, w której gminy mają na ogół charakter wielofunkcyjny przejściowy.

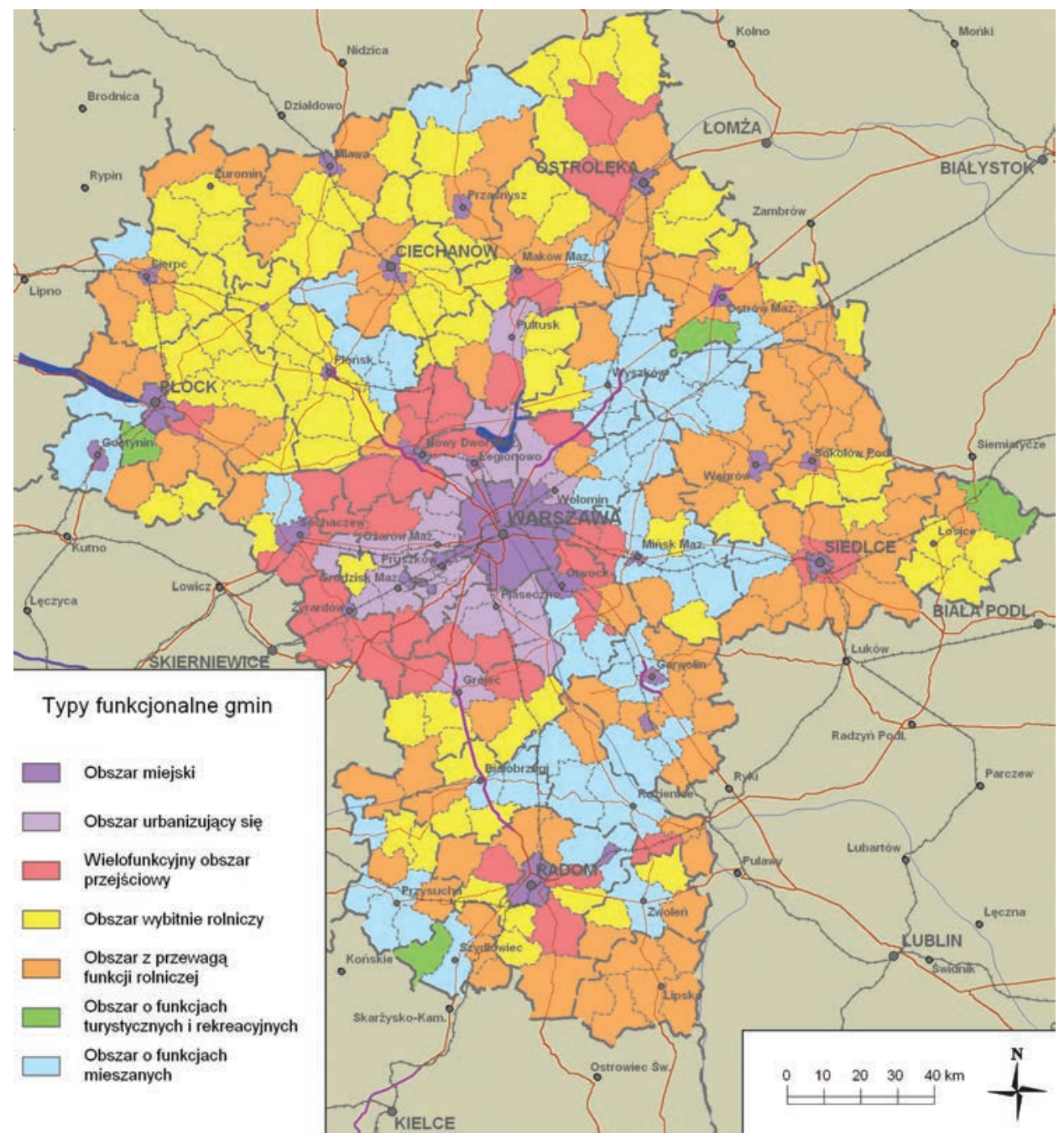

Ryc. 3. Struktura funkcjonalna gmin w woj. mazowieckim, 2010

Źródło: T. Komornicki i in. 2012 
Obszary urbanizujące się otoczone są przez wielofunkcyjne obszary przejściowe, które cechuje występowanie struktur punktowych i powierzchniowych o różnym stopniu natężenia. Stanowią one formę przejściową pomiędzy obszarami urbanizowanymi, a tradycyjnymi obszarami wiejskimi. Najszerszą strefę tworzą w zachodniej części województwa sięgając do granic administracyjnych regionu. Jest to rezultat rozwoju szerokiej „strefy komunikacyjnej” pomiędzy Warszawą i Łodzią. Obszary przejściowe występują też nieregularnie wokół ośrodków subregionalnych. Na wschód od Warszawy i Radomia leżą zwarte kompleksy gmin wiejskich o funkcjach mieszanych. Są to tereny wiejskie z przewagą funkcji powierzchniowych (rolnictwo, leśnictwo, turystyka i rekreacja), ale bez wyraźnej specjalizacji. Podobne jednostki wykształciły się punktowo w sąsiedztwie Płocka, Płońska i Przysuchy.

Najliczniejszą grupę tworzą gminy o funkcjach rolniczych. Są one położone na ogół poza strefą metropolitalną Warszawy i otaczają ośrodki subregionalne. Można wyróżnić dwie ich podgrupy: obszary wybitnie rolnicze i obszary z przewagą funkcji rolniczej. Pierwsze charakteryzują się dominacją funkcji rolniczej, wyraźną koncentracją użytków rolnych, korzystnymi warunkami przyrodniczymi dla produkcji rolnej oraz wysokim udziałem gospodarstw towarowych. Drugą podgrupe cechuje przewaga rolnictwa nad innymi sektorami gospodarki, przy czym jest ono zróżnicowane.

Badania struktury funkcjonalnej obszarów wiejskich realizowane w Instytucie Geografii i Przestrzennego Zagospodarowania od ponad 30 lat, przy zastosowaniu tej samej metody i podobnych wskaźników diagnostycznych, pozwalają ocenić jej zmienność [Stola 1993; Bański, Stola 2002; Bański, Czapiewski 2016]. Porównanie struktur w 1988 r. i 2010 r. wskazuje na bardzo wyraźne wzmocnienie funkcji pozarolniczych na terenach wiejskich położonych na zachód od Warszawy. W 1988 r. zidentyfikowano w tej części tylko 6 gmin o przewadze funkcji pozarolniczych z udziałem rolnictwa, 1 gminę o przewadze funkcji mieszkaniowej i 1 gminę z funkcjami mieszanymi. Pozostałe jednostki miały silne związki z sektorem rolnictwa, co wynikało z dobrze wykształconej strefy żywicielskiej stolicy (w tym liczna grupa gospodarstw warzywniczych). W 2010 r. znaczenie rolnictwa zostało tu zredukowane na tyle, że obszary wiejskie mają prawie wyłącznie funkcje pozarolnicze. Natomiast na wschód od Warszawy i Radomia powiększył się w analogicznym okresie zasięg obszarów o funkcjach mieszanych, głównie kosztem rolnictwa. Cały pozostały obszar Mazowsza zarówno w 1988 r., jak i 2010 r. charakteryzowała funkcja rolnicza, czyli zmiany struktury funkcjonalnej na tradycyjnych obszarach wiejskich były mniejsze niż w strefie oddziaływania Warszawy.

Stan rozwoju społeczno-ekonomicznego obszarów wiejskich woj. mazowieckiego na tle innych regionów kraju jest raczej korzystny. Większość analizowanych wskaźników rozwojowych przewyższa przeciętne wartości dla Polski (ryc. 4). Z drugiej jednak strony charakteryzują się największymi w kraju wewnątrzregionalnymi dysproporcjami ekonomicznymi i nadal widocznym procesem polaryzacji przestrzennej pomiędzy obszarem metropolitalnym a terenami oddalonymi od głównego rdzenia rozwojowego. 
Warto podkreślić wysoką konkurencyjność Mazowsza na krajowym rynku ze względu na znaczący udział ludności z wyższym wykształceniem oraz ponadprzeciętnie dodatnie saldo migracji. Dotyczy to jednak przede wszystkim ośrodków miejskich i obszarów podmiejskich. Niska, w porównaniu z resztą kraju, jest przede wszystkim aktywność społeczna wsi, wyposażenie w infrastrukturę wodno-kanalizacyjną oraz jej atrakcyjność turystyczna. W zakresie struktury przestrzennej rolnictwa, niemal wszystkie badane cechy, z wyjątkiem struktury agrarnej, cechują się ponadprzeciętnymi wartościami w skali kraju.

Najkorzystniej pod względem rozwoju gospodarczego wypadają gminy wiejskie położone w granicach Obszaru Metropolitalnego Warszawy, zwłaszcza w jego południowej i zachodniej części. Wynika to z wysokich wartości wskaźnika atrakcyjności lokalizacyjnej oraz wysokich dochodów własnych gmin w przeliczeniu na 1 mieszkańca. Korzystne uwarunkowania gospodarcze występują również w gminach położonych wokół ośrodków subregionalnych, co jest związane z funkcjonowaniem relatywnie dużej liczby podmiotów gospodarczych oraz znaczeniem tych miast, jako rynków pracy.

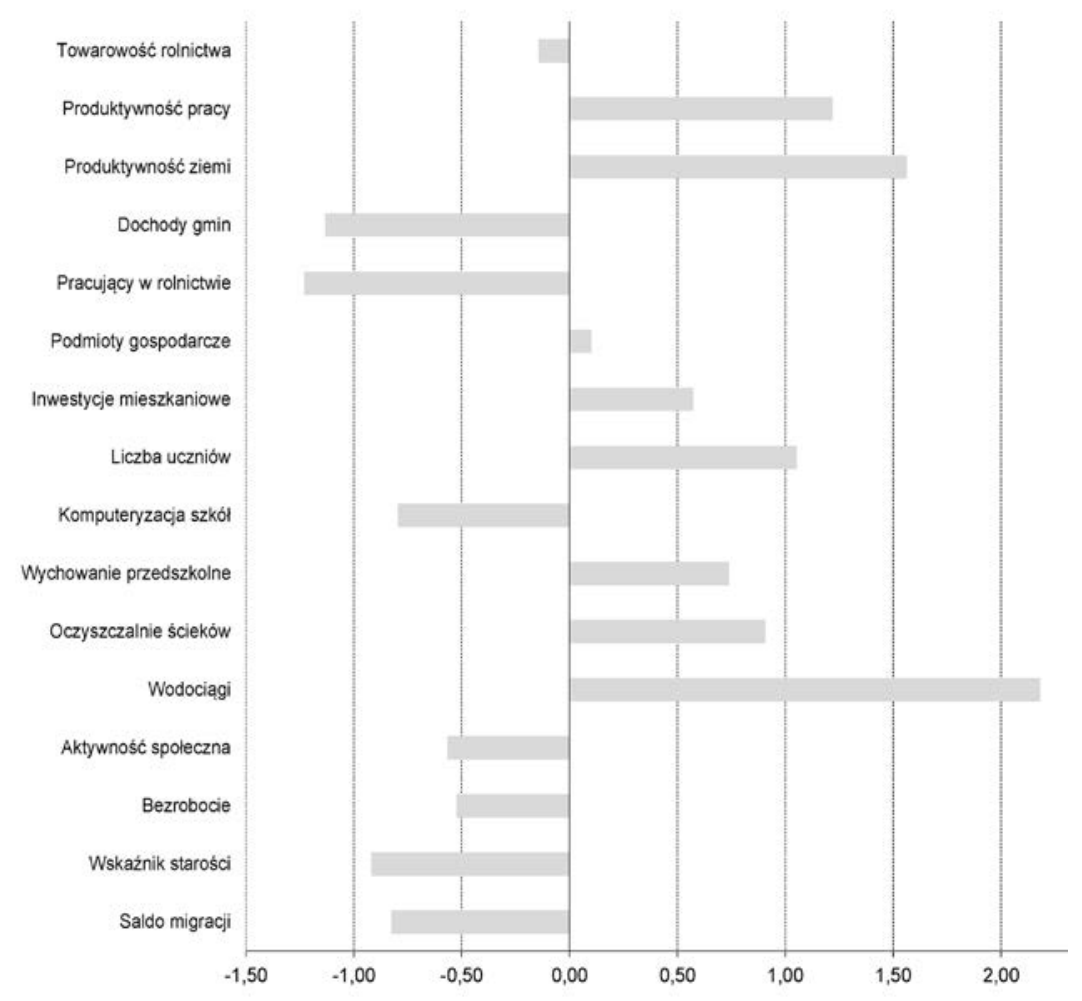

Ryc. 4. Odchylenie od średnich wartości dla Polski wskaźników społeczno-ekonomicznych w woj. mazowieckim w $2010 \mathrm{r}$.

Źródło: Szanse i zagrożenia ... 2012 


\section{Trendy rozwojowe obszarów wiejskich - dyskusja}

Obszary wiejskie w woj. mazowieckim charakteryzują się podobnymi procesami społeczno-ekonomicznymi jak inne regiony w kraju; różnić się mogą natomiast ich natężeniem i kierunkiem. Wśród nich najważniejszą rolę odgrywają zjawiska demograficzne, procesy rozwojowe w sąsiedztwie dużych miast, kształtowanie się nowych funkcji gospodarczych, wzrost powiązań funkcjonalnych obszarów wiejskich z ośrodkami centralnymi oraz zmiany strukturalne w sektorze rolnictwa.

Omawiany region cechuje systematyczna koncentracja ludności w największych ośrodkach miejskich, co jest rezultatem odpływu migracyjnego z przeważającej części terenów wiejskich, w tym szczególnie z obszarów peryferyjnych. Migrują przede wszystkim ludzie młodzi i aktywni, poszukujący lepszych warunków pracy i wyższych standardów życia. Na terenach „wysyconych” demograficznie kształtują się problemy związane z zachwianą strukturą płci i wieku. Proces migracji niesie za sobą rozwój osadnictwa w strefach podmiejskich oraz zanik najmniejszych jednostek osadniczych, głównie na terenach peryferyjnych.

Najbardziej dynamicznym zjawiskiem jest wyludnianie się wsi, głównie na obszarach o funkcjach rolniczych, położonych peryferyjnie wobec ośrodka centralnego (południowa, północna i północno-wschodnia część woj. mazowieckiego). W jego wyniku zmniejsza się gęstość zaludnienia oraz przeciętna wielkość osiedli wiejskich. Obszary największego ubytku ludności charakteryzuje już dziś sieć małych wsi, które w niedalekiej przyszłości mogą ulec całkowitej „degradacji” demograficznej. Krajobraz porzuconych gospodarstw jest tam coraz powszechniejszy. Na obszarach regresu demograficznego nie można też oczekiwać nowych inwestycji i rozwoju infrastruktury technicznej, co pogłębia ich problemy społeczno-ekonomiczne. Drugim niekorzystnym zjawiskiem jest starzenie się mieszkańców tych obszarów, głównie w wyniku odpływu młodzieży do miast. Migrują najaktywniejsi i najlepiej wykształceni. Pochodną tych niekorzystnych zmian jest (lub może być) stagnacja małych miast, których rozwój zależy w znacznym stopniu od sytuacji na otaczających je obszarach wiejskich (ryc. 5).

Współczesna wieś w strefie podmiejskiej Warszawy i innych większych ośrodków miejskich pełni funkcje rezydencjalne, usługowe i produkcyjne. Najważniejszą rolę odgrywa funkcja mieszkaniowa, która stymuluje rozwój infrastruktury technicznej i społecznej. Mieszkalnictwo rozwija się intensywnie wzdłuż ciągów komunikacji kolejowej i drogowej. Można oczekiwać, że w miarę rozwoju infrastruktury drogowej, poprawiającej dostępność do Warszawy, strefa presji inwestorów budowlanych będzie się rozszerzać do odległości czasowej 45-60 min od miasta. Częstym zjawiskiem jest nadmierna presja inwestycyjna, której efektem są konflikty przestrzenne i problemy z utrzymaniem ładu przestrzennego. Napływ ludności pociąga za sobą rozwój usług i handlu. 


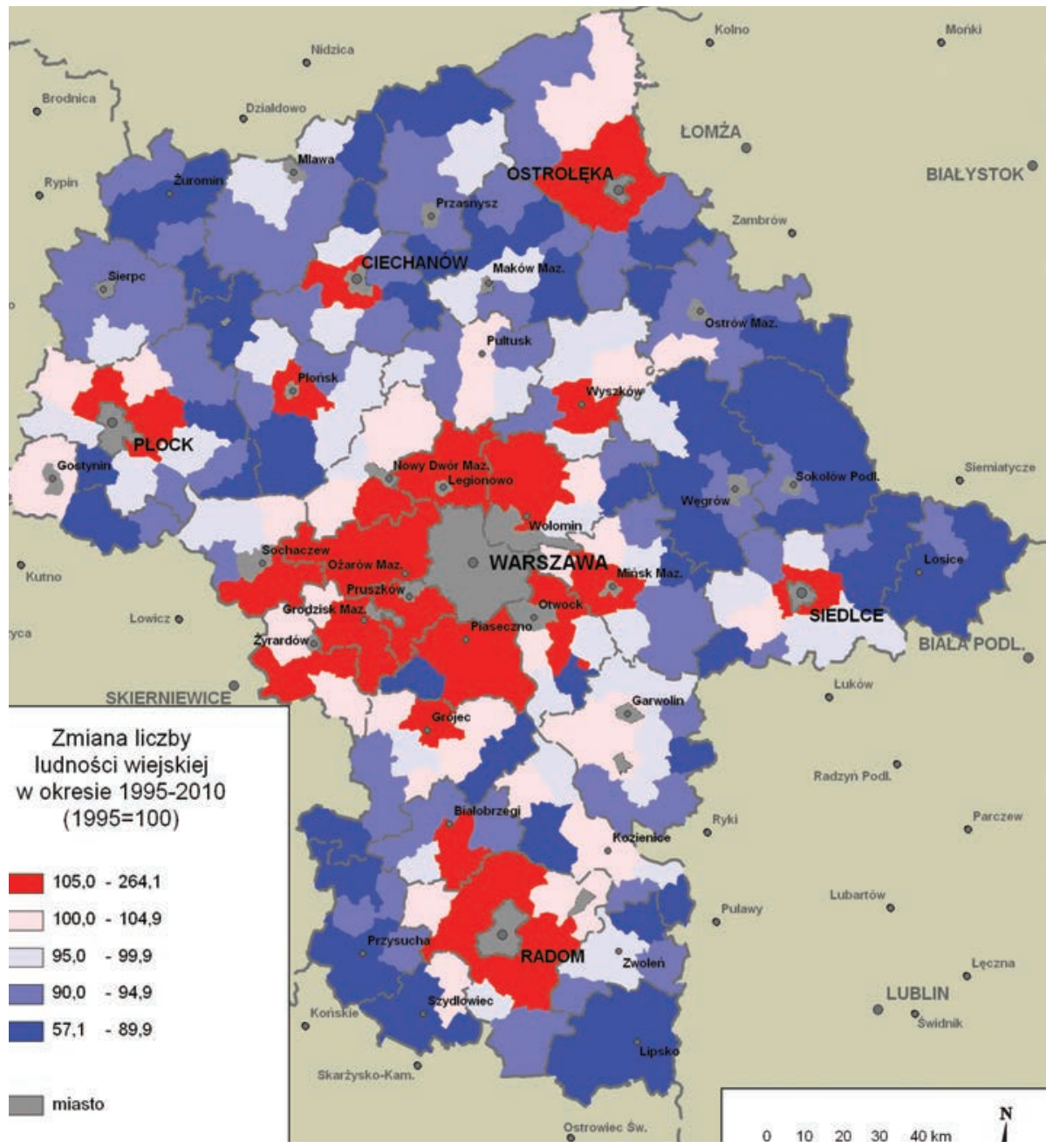

Ryc. 5. Zmiana liczby ludności wiejskiej w gminach województwa mazowieckiego w latach 1995-2010

Źródło: Trendy Rozwojowe Mazowsza 2012

Można oczekiwać, że w perspektywie najbliższych kilkunastu lat teeny podmiejskie zatracą całkowicie wiejski charakter. Pozostaną prawdopodobnie niewielkie enklawy otwartego krajobrazu wynikające z funkcji ochronnych i rekreacyjnych, działalności nielicznych wyspecjalizowanych gospodarstw rolnych lub braku możliwości rozwoju osadnictwa. W związku z tym pojawią się nowe wyzwania przed polityką przestrzenną i wzrośnie potrzeba monitorowania zjawisk związanych z rozwojem nowej sieci osadniczej. Należy też zwrócić większą uwagę na to, że w sąsiedztwie dużych miast koncentrują się największe osiedla wiejskie. W związku z napływem ludności w ostatnich kilkunastu latach, 
jednostki te powiększają się i nabierają cech obszarów miejskich. Wywołuje to różnorodne konflikty związane z przestrzennym układem wsi, rozpraszaniem zabudowy, brakiem utwardzonych dróg dojazdowych do posesji, utrudnieniami komunikacyjnymi w godzinach dojazdu i powrotu z pracy itp.

Rolnictwo Mazowsza jest zróżnicowane przestrzennie zarówno pod względem kierunków produkcji, jak i poziomu towarowości. Fundusze unijne przeznaczone dla wsi i rolnictwa uruchomiły nowe procesy w sektorze żywnościowym, w tym zdynamizowały rozwój towarowego i intensywnego rolnictwa, wzrosła efektywność produkcji rolnej, powstały grupy producentów rolnych podejmujące konkurencję na europejskim rynku żywności, spadło zatrudnienie w rolnictwie i poprawiła się struktura agrarna gospodarstw rolnych, wzrasta znaczenie rolnictwa ekologicznego. Szansą dla rozwoju mazowieckiego rolnictwa jest istnienie największego wewnętrznego rynku zbytu na produkty żywnościowe w Polsce - aglomeracji warszawskiej. Tutejsze rolnictwo jest konkurencyjne w skali kraju głównie za sprawą silnie rozwiniętego sektora sadowniczego i ogrodniczego w południowej i zachodniej części województwa (grójecko-skierniewicki rejon sadowniczy, radomski rejon warzywniczy). Około 30\% powierzchni polskich sadów znajduje się na Mazowszu i zbiera się tu ponad $40 \%$ krajowej produkcji owoców (ponad połowa krajowej produkcji jabłek i jedna czwarta produkcji truskawek pochodzą z mazowieckich sadów i plantacji). Duży potencjał rozwojowy ma również prężnie rozwijająca się hodowla bydła w północnych powiatach województwa (północno-wschodni rejon mleczarski). Miejscami występują obszary intensywnej i wyspecjalizowanej uprawy warzyw i krzewów owocowych lub chowu zwierząt (np. zespoły wsi pod Żurominem i Siedlcami wyspecjalizowane w produkcji drobiu).

W najbliższych kilkunastu latach należy oczekiwać wzrostu przestrzennej specjalizacji produkcji i poziomu towarowości gospodarstw rolnych. Warto w tym kontekście pokusić się o zdiagnozowanie zróżnicowania warunków rozwoju tego sektora i promocję kierunków produkcji uzyskujących najlepsze efekty produkcyjne. Należy przy tym intensyfikować wsparcie dla organizacji producentów rolnych i integrację pionową z sektorem przetwórstwa. Szansą dla małych gospodarstw rolnych, zlokalizowanych w północnej i wschodniej części województwa, jest rozwój rolnictwa ekologicznego, wspierającego usługi agroturystyczne.

Analiza potencjału turystycznego obszarów wiejskich wg województw wykonana w 2012 r. wykazała, że woj. mazowieckie zajmuje 6 miejsce w kraju pod względem walorów przyrodniczo-kulturowych, 14 miejsce pod względem zagospodarowania turystycznego i 8 miejsce pod względem warunków ekonomiczno-infrastrukturalnych [Turystyka wiejska ... 2012]. Na tej podstawie można stwierdzić, że Mazowsze ma „przeciętne” warunki do rozwoju turystyki wiejskiej. Jednakże Warszawa jest największym w kraju rynkiem usług turystycznych, dlatego na niektórych obszarach wiejskich od dawna można obserwować rozwój tego sektora, związany głównie z wypoczynkiem świątecznym i sobotnioniedzielnym ( $\mathrm{zw}$. turystyka weekendowa). Dotyczy to przede wszystkim doliny Wisły, Bugu i Narwi oraz sąsiedztwa mniejszych rzek i zbiorników wodnych oraz większych kompleksów leśnych. 
Duże szanse rozwojowe stoją przed agroturystyką. Badania wskazują że największe obłożenie kwater agroturystycznych występuje w regionach z dużym ośrodkiem miejskim. Gospodarstwa, których właściciele deklarowali, że przyjmują rocznie około 1000 i więcej osób, położone były w pobliżu dużych aglomeracji z dobrą dostępnością komunikacyjną (Warszawa, Łódź, Kraków, konurbacja śląska). Takie obiekty mogą oferować usługi nie tylko dla pojedynczych turystów, ale również dla dużych grup zorganizowanych (np. zielone szkoły), które wpływają na dobry wynik pod względem liczby przyjmowanych osób. Dodatkowym atutem jest brak sezonowości usług, jak to ma miejsce na pojezierzach lub wybrzeżu. Poza obszarami tradycyjnie turystycznymi, kwatery agroturystyczne stanowią niejednokrotnie jedyne obiekty noclegowe. Brak konkurencyjnej bazy noclegowej sprawia, że są one również wykorzystywane w różnych, innych niż wypoczynkowo-rekreacyjne celach [Bednarek-Szczepańska 2010].

\section{Podsumowanie}

Współczesne zmiany na obszarach wiejskich woj. mazowieckiego zwiększają jego polaryzację przestrzenną. Przeważają raczej zjawiska sprzyjające rozwojowi społecznoekonomicznemu regionu, ale ich natężenie jest wyraźnie zróżnicowane. Stąd wzrost różnic przestrzennych w regionie. Najbardziej dynamiczne zmiany występują w Warszawskim Obszarze Metropolitalnym i w sąsiedztwie ośrodków subregionalnych. Wśród najistotniejszych procesów należy wymienić napływ nowych mieszkańców z centrów miast, rozbudowę sieci osadniczej, rozwój funkcji usługowych i handlowych, marginalizację sektora rolnictwa. Niosą one ze sobą szereg wyzwań związanych z łagodzeniem konfliktów przestrzennych i utrzymaniem ładu przestrzennego (np. przeciwdziałanie rozpraszaniu zabudowy i niekontrolowanego rozlewania się strefy osadnictwa). Powszechnie uważa się, że za żywiołowym rozwojem przestrzennym nie nadąża system zarządzania przestrzenią oraz przepisy kształtujące politykę planowania przestrzennego.

Dynamika zmian na „tradycyjnych” obszarach wiejskich, czyli położonych w większej odległości od ośrodków centralnych, jest mniejsza i wiąże się głównie z rozwojem sektora żywnościowego i rzadziej pojawianiem się nowych funkcji gospodarczych. Podstawowe wyzwania wynikają $\mathrm{z}$ kształtowania racjonalnej struktury gospodarstw rolnych i odpowiednich kierunków ich produkcji. Ważnym zagadnieniem jest poszukiwanie i wdrażanie na terenach wiejskich nowych funkcji gospodarczych, których rezultatem będzie różnicowanie dochodów gospodarstw na wsi (turystyka, energia odnawialna, przetwórstwo żywności). 


\section{Literatura}

Bański J., 2008, Strefa podmiejska - już nie miasto, jeszcze nie wieś, [w:] A. Jezierska-Thöle, L. Kozłowski (red.), Gospodarka przestrzenna w strefie kontinuum miejsko-wiejskiego w Polsce, Wydawnictwo Naukowe UMK, Toruń, s. 29-43.

Bański J., (red.), 2010, Atlas Rolnictwa Polski, IGiPZ PAN, Warszawa.

Bański J., (red.), 2009, Analiza zróżnicowania i perspektyw rozwoju obszarów wiejskich w Polsce do 2015 roku, Studia Obszarów Wiejskich, 16, IGiPZ PAN, PTG, Warszawa.

Bański J., 2014, Wspótczesne typologie obszarów wiejskich w Polsce - przegląd podejść metodologicznych, Przegląd Geograficzny, 86, 4, s. 441-470.

Bański J., (red.), 2016, Atlas obszarów wiejskich w Polsce, IGiPZ PAN, Warszawa.

Bański J., Stola W., 2002, Przemiany struktury przestrzennej i funkcjonalnej obszarów wiejskich w Polsce, Studia Obszarów Wiejskich, 3, IGiPZ PAN, PTG, Warszawa.

Bański J., Czapiewski K., Bednarek-Szczepańska M., 2009, Miejsce obszarów wiejskich w aktualnych strategiach województw - kierunki i cele rozwoju a rzeczywistość, Studia Obszarów Wiejskich, 19, IGiPZ PAN, PTG, Warszawa.

Bański J., Czapiewski K., 2016, Funkcje gospodarcze, [w:] J. Bański (red.) Atlas obszarów wiejskich w Polsce, IGiPZ PAN, Warszawa, s. 89-112.

Bednarek-Szczepańska M., 2010, Rola podmiotów lokalnych w rozwoju turystyki wiejskiej na wybranych obszarach Lubelszczyzny, Studia Obszarów Wiejskich, 23, IGiPZ PAN, PTG, Warszawa.

Czapiewski K., 2010, Koncepcja wiejskich obszarów sukcesu społeczno-gospodarczego $i$ ich rozpoznanie w województwie mazowieckim, Studia Obszarów Wiejskich, 22, IGiPZ PAN, PTG, Warszawa.

Komornicki T., Czapiewski K., Solon B. (red.), 2012, Zagospodarowanie infrastrukturalne i kapitał fizyczny oraz policentryczność rozwoju Mazowsza, Trendy Rozwojowe Mazowsza, 4, MBPR, Warszawa.

Lisowski A., Grochowski M., 2008, Procesy suburbanizacji. Uwarunkowania, formy i konsekwencje, [w:] K. Saganowski, M. Zagrzejewska-Fiedorowicz, P. Zuber (red.), Ekspertyzy do Koncepcji Przestrzennego Zagospodarowania Kraju 2008-2033, 1, Ministerstwo Rozwoju Regionalnego, Warszawa, s. 217-281. 


\section{WYZWANIA ROZWOJOWE NA OBSZARACH WIEJSKICH W WOJEWÓDZTWIE MAZOWIECKIM Jerzy Bański}

Mazowsze 2020, Rzecz o rozwoju Mazowsza, 2013, Instytut Badań Systemowych, Warszawa.

Stola W., 1993, Struktura przestrzenna i klasyfikacja funkcjonalna obszarów wiejskich Polski, Dokumentacja Geograficzna, 3, IGiPZ PAN, Warszawa.

Strategia rozwoju turystyki w województwie mazowieckim na lata 2014-2020, 2015,https://bip. mazovia.pl/downloadStat/gfx/.../strategia_rozwoju_turystyki_2014-2020.pdf [dostęp: 08.03.2018].

Strategia rozwoju województwa mazowieckiego do roku 2020 (aktualizacja), 2006, Samorząd Województwa Mazowieckiego, Warszawa.

Strategia rozwoju województwa mazowieckiego do 2030 roku. Innowacyjne Mazowsze, 2013, Samorząd Województwa Mazowieckiego, Warszawa.

Szanse i zagrożenia oraz potencjalne kierunki rozwoju obszarów wiejskich w Polsce w ujęciu regionalnym, Raport podsumowujący, 2012, Agrotec Polska, IGiPZ PAN, Warszawa.

Turystyka wiejska, w tym agroturystyka, jako element zrównoważonego i wielofunkcyjnego rozwoju obszarów wiejskich, Raport końcowy, 2012, Agrotec Polska, IGiPZ PAN, Warszawa. 


\section{Development challenges in rural areas in the Mazovieckie Voivodeship}

\section{ABSTRACT}

In the spatial structure of the Mazovieckie Voivodeship two main elements can be distinguished - Warsaw, including rural areas in its vicinity, and the remaining territory, including subregional centers, small towns and rural areas. Modern economic structures encompassing innovative industry branches and services are concentrated in Warsaw and, to a lesser extent, in Radom and Płock. By contrast, in the remaining part of the region, the leading role is played by the agricultural sector which is characterized by considerable spatial diversity.

The aim of this study is to diagnose contemporary changes in the spatial structure of rural areas in Mazovia and related development challenges. The primary statistical material has been derived from the Agricultural Census of 2010 and the Local Data Bank (Central Statistical Office), providing material for detailed analysis. The study consists of three parts. The first one comprises an evaluation of the Development Strategy of the Mazovieckie Voivodeship which affected rural development at the turn of the first and second decades of the current century. Furthermore, the Strategy discusses progress in planning in rural areas. The second part characterizes the functional structure of rural areas in the Mazovieckie Voivodeship and its transformation and provides a diagnosis concerning rural socio-economic development. The third part discusses contemporary development trends occurring in rural areas and challenges associated with them.

The present-day changes in the rural areas of the Mazovieckie Voivodeship enhance spatial polarization within the province. In general, there is a prevalence of phenomena which are favorable for the socio-economic development of the region, however their intensity is definitely diverse. Hence the increase of spatial disparities in the region. The most dynamic changes occur within the Warsaw Metropolitan Area as well as in the vicinity of subregional centers. On the other hand, changes occurring in rural areas located at a distance from growth poles are of considerably smaller scale and are mostly associated with the development of the food sector and to a lesser extent the emergence of new economic functions. Basic challenges result from the evolution of a rational farm structure and implementing appropriate production goals.

Key words: rural areas, Mazovia, spatial structure, spatial development, agriculture

\footnotetext{
Prof. dr hab. Jerzy Bański - profesor o specjalności geografia społeczna w Instytucie Geografii i Przestrzennego Zagospodarowania PAN (IGiPZ PAN) oraz na Uniwersytecie Marii Curie-Skłodowskiej w Lublinie. Obszary badawcze: geografia wsi, użytkowanie ziemi, rozwój lokalny i regionalny oraz planowanie przestrzenne. Pełnione funkcje: od 2018 r. dyrektor IGiPZ PAN. W latach 2006-2012 był Przewodniczącym Polskiego Towarzystwa Geograficznego, a od 2016 r. jest Przewodniczącym Komisji Rozwoju Lokalnego i Regionalnego Międzynarodowej Unii Geograficznej. Autor ponad 370 publikacji (w tym 24 monografii i ponad 180 artykułów naukowych). Kierował 43 projektami badawczymi i ekspertyzami, uczestniczył w 44 innych projektach (w tym ESPON, FP6, FP7 i Horizon). Kontakt do autora: Instytut Geografii i Przestrzennego Zagospodarowania PAN, 00-818 Warszawa, ul. Twarda 51/55; e-mail:jbanski@twarda.pan.pl

Jerzy Bański is a full professor of human geography in the Institute of Geography and Spatial Organization, Polish Academy of Sciences (IGSO PAS) and a Professor of Maria Curie-Sklodowska University in Lublin, Poland. His main research interests include: rural geography, land use, regional policy, spatial organization and local development. Since 2018 he is the Director of the IGSO PAS. In 2006-2012 he was the President of the Polish Geographical Society and from 2016 is the Head of the Commission on Local and Regional Development of the International Geographical Union. Jerzy Bański is the author of over 370 publications (including 24 books and more than 180 peer reviewed papers). He was the co-ordinator of 43 research projects and the member of 44 other projects, including ESPON, FP6, FP7 and Horizon projects. Contact: Institute of Geography and Spatial Organization PAS; 00-818 Warszawa, ul. Twarda 51/55; e-mail:jbanski@twarda.pan.pl
} 